\title{
A state-of-art review on supplier selection problem
}

\author{
Tahereh Khodadadzadeh $^{\mathrm{a}^{*}}$ and Seyed Jafar Sadjadi ${ }^{\mathrm{b}}$
}

${ }^{a}$ Department of Industrial Engineering (Digital Unit), Iran University of Science \& Technology, Tehran, Iran

${ }^{b}$ Department of Industrial Engineering, Iran University of Science \& Technology, Tehran, Iran, Member of Center of Excellent in Industrial Engineering

\section{H R O N C L E ABS T R A T}

Article history:

Received October 2, 2012

Received in Revised Format

January 23, 2013

Accepted February 15, 2013

Available online

February 232013

Keywords:

Data envelopment analysis

Supplier selection

Multiple criteria decision making

\begin{abstract}
Many supplier selection problems are involved with various criteria such as quality of supplier, price, delivery time, etc. This paper presents a survey on the implementation of using different multi criteria decision making (MCDM) methods for supplier selection problems. The reviews covers recent advances of MCDM techniques such as data envelopment analysis (DEA), analytical hierarchy process, etc. over the period 2000-2012. The review also reveals that nearly $60 \%$ of the applications are associated with business unit, $15 \%$ is related to economy, $9 \%$ is devoted to service and development and $8 \%$ is dedicated to research and development. In our survey, DEA has become the most popular technique for supplier selection problem followed by Technique for Order Preference by Similarity to Ideal Solution (TOPSIS) and Analytical Hierarchy Process (AHP).
\end{abstract}

\section{Introduction}

Supplier selection is one of the most important issues in any production units and choosing a good supplier may help increase productivity and efficiency of business units. During the past few years, there have been different methods associated with supplier selection problems. Supplier selection plays an important role on efficiency of production planning. There are many methods for supplier selection and most of them are involved using multi criteria decision making. DEA is one of the most important techniques for measuring relative efficiencies of various suppliers. In this paper, we review recent advances of different techniques of implementing different techniques such as DEA methods for supplier selection problem. During the past few years, there have been tremendous efforts on using DEA to measure relative efficiencies of suppliers. Problem-solving techniques such as linear programming, test assumptions, and methods for optimizing multiple criteria decision making (MCDM) are used to obtain good solutions. MCDM is the argument that the decision-making (DM) process in the presence of different criteria sometimes incompatible with each other methods. One problem with this method is the selection of an appropriate procedure in hypothetical situations. This

* Corresponding author. Tel: +9877240129

E-mail addresses: takhodadadzadeh@mail.com (T. Khodadadzadeh)

(C) 2013 Growing Science Ltd. All rights reserved. doi: $10.5267 /$ j.ds1.2013.03.001 
section attempts to briefly describe the various methods of problem solving. MCDM models can be divided into two categories as follows,

\section{i) Multi objective decision making (MODM)}

Multi objective decision making (MODM) method where we consider different objective functions such and plan to find so called Pareto solutions. There are different approaches to handle MODM problems such as goal programming, Lexicography, LP-norm, etc.

\section{ii) Multi attribute decision making (MADM)}

In multi attribute decision making (MADM), we look to rank different alternatives based on various attributes. There are literally different methods for ranking suppliers based on multiple criteria such as quality, price, etc.

\section{Data Envelopment Analysis (DEA)}

Data Envelopment Analysis (DEA) measures the relative efficiency of Decision Making (DM) of weighted outputs to weighted inputs. DEA has been used in a variety of fields, such as measuring and comparing the performance of banks (Portela et al., 2004; Hemmati et al., 2013), insurance industry ( Bowlin et al., 2003), Schools and universities (Cordero-Ferrera, 2010; Pedraja-Chaparro \& SantínGonzález, 2010; Thanassoulis et al., 2011; Kao et al., 2011; Sohn \& Kim, 2012), hospitals (Amado \& Dyson, 2009; Xu et al., 2010; Färe et al., 2011; Hu et al., 2012; Hu et al., 2012), retail chains ( Mostafa, 2010; Vaz et al., 2010; Almeida \& Dias, 2012), Capital market (Basso \& Funari, 2003; Azadeh et al., 2009; Ho et al., 2011; Huang et al., 2012), Military bases (Portela et al., 2004), Location (Amindoust et al., 2012). Table 1 demonstrates some of the recent advances of DEA applications in various areas.

\section{Table 1}

Different issues concerning the application of DEA (2000-2013)

\begin{tabular}{|c|c|c|}
\hline Author(s) & Application & No. \\
\hline $\begin{array}{l}\text { Ramanathan, 2005; Wang \& Cullinane, 2006; Ozbek et al., 2009; Wu et al., 2010; Ju et al., 2012; Haralambides \& Gujar, } \\
\text { 2012. }\end{array}$ & Transportation & 6 \\
\hline $\begin{array}{l}\text { Liu et al., 2000; Førsund \& Hjalmarsson, 2004; Mostafa, 2010; Farzipoor Saen, 2010; Lozano \& Villa, 2010; Lin et al., 2011; } \\
\text { Xuanli \& Yuan, 2011; Wei \& Chang, 2011; Ruiz \& Sirvent, 2011; Cook \& Zhu, 2011; Zhang et al., 2012; Falagario et al., } \\
\text { 2012; Luo et al., 2012. }\end{array}$ & Economic & 13 \\
\hline Portela et al., 2004; Hemmati et al., 2013. & Bank & 2 \\
\hline Basso and Funari, (2003); Azadeh et al., 2009; Ho et al., 2011; Huang et al., 2012. & Investment & 4 \\
\hline $\begin{array}{l}\text { Lozano \& Villa, 2005; Park, 2007; Wong \& Wong, 2007; Bao et al., 2008; Soleimani-damaneh, 2009; Alem et al., 2009; } \\
\text { Dotoli et al., 2010; Barnum et al., } 2010 .\end{array}$ & Business & 8 \\
\hline Saranga \& Moser, 2010; Chen, 2010; Huang et al., 2012. & Marketing & 3 \\
\hline $\begin{array}{l}\text { Kang, 2010; Samoilenko \& Osei-Bryson, 2010; Milioni et al., 2011; Chen \& Delmas, 2011; Kerstens \& Woestyne, 2011; You } \\
\text { \& Yan, 2011; Zhou et al., 2011; Liu \& Lu, 2012; Wang et al., 2012; Guedes et al., 2012; Akçay, 2012; Samoilenko, 2012; } \\
\text { Samoilenko, 2012; Amindoust et al., 2012; Davoodi et al., 2012; Huang \& Kao, 2012; Huang \& Kao, 2012; Puri \& Yadav, } \\
\text { 2013; }\end{array}$ & Organization & 18 \\
\hline $\begin{array}{l}\text { Braglia \& Petroni, 2000; Triantis, 2004; Greasley, 2005; Sevkli et al., 2007; Chuang et al., 2009; Feng \& Jiang, 2009; Xu et } \\
\text { al., 2009; Bandyopadhyay, } 2011 .\end{array}$ & Product & 8 \\
\hline $\begin{array}{l}\text { Liu and Wu, 2005; Seydel, 2006; Talluria et al., 2006; Ramanathan, 2007; Çelebi \& Bayraktar, 2008; Zhao \& Sun, 2008; Wu } \\
\text { \& Blackhurst, 2009; Ross \& Buffa, 2009; Rabbani, 2009; Zhenhua, 2009; Hatefi et al., 2009; Wu, 2009; Lin et al., 2009; } \\
\text { Buffa \& Ross, 2010; Toloo \& Nalchigar, 2010; Wen \& Chi, 2010; Kang \& Lee, 2010; Azadeh \& Alem, 2010; Vaz et.al., } \\
\text { 2010; Kuo et.al., 2010; Wu, 2010; Kuo et.al., 2010; Shi et.al., 2010; Zeydan et.al.; 2011; Chen \& Yan, 2011; Azadi \& } \\
\text { Farzipoor Saen, 2011; Wu \& Olson, 2012; Almeida \& Dias, 2012; Almeida \& Dias, 2012; Noorizadeh et.al., 2013; Puri \& } \\
\text { Yadav, 2013; Arabzad et.al., 2013; Noorizadeh et.al., 2013; Amindoust et.al., 2013. }\end{array}$ & Supplier chain & 37 \\
\hline Amado \& Dyson, 2009; Xu et.al., 2010; Färe et.al., 2011; Hu et.al., 2012. & Health & 4 \\
\hline Woodbury \& Dollery, 2004; Geymueller, 2009; Wei \& Jiansheng, 2011; Çelen \& Yalçın, 2012 & Service & 4 \\
\hline Bowlin et al., 2003 & Insurance & 1 \\
\hline Bartilow \& Eom, 2009 & Police & 1 \\
\hline Cordero-Ferrera et.al., 2010; Thanassoulis et.al., 2011; Kao et.al., 2011; Sohn \& Kim, 2012; Azizi \& Paktinat, 2013. & Education & 5 \\
\hline Vakkuri, 2003; Revilla et al., 2003; Meng et al., 2008; Khalili et al., 2010; Souza et al., 2011; Lin et al., 2013. & Research & 6 \\
\hline Krivonozhko et al., 2004; Joro \& Viitala, 2004; Toloo \& Nalchigar, 2011, Tac & $\begin{array}{l}\text { Mathematical } \\
\text { models }\end{array}$ & 4 \\
\hline
\end{tabular}




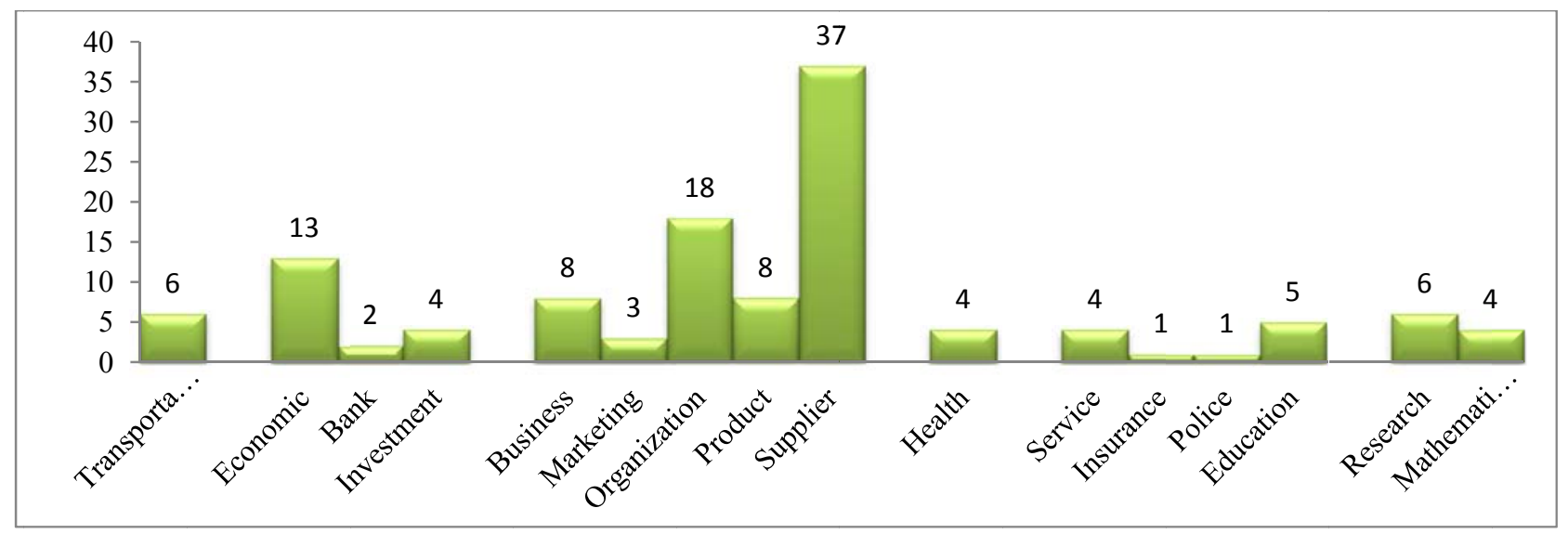

Fig.1.Different issues concerning the application of DEA (2000-2013)

Fig. 1 shows frequencies of different scientific fields of using DEA applications. Fig. 2 demonstrates various applications of DEA method. According to Fig. 2, 15\% is related to economy, 9\% is devoted to service and development and $8 \%$ is dedicated to research and development. In our survey, DEA has become the most popular technique for supplier selection problem followed by Technique for Order Preference by Similarity to Ideal Solution (TOPSIS) and Analytical Hierarchy Process (AHP).

Table 2

General categories of the application of DEA in industries

\begin{tabular}{lcccccc}
\hline Industry & Transportation & Economic & Business & Health & Service & Research \\
\hline Number of essays & 6 & 19 & 74 & 4 & 10 & 10 \\
\hline
\end{tabular}

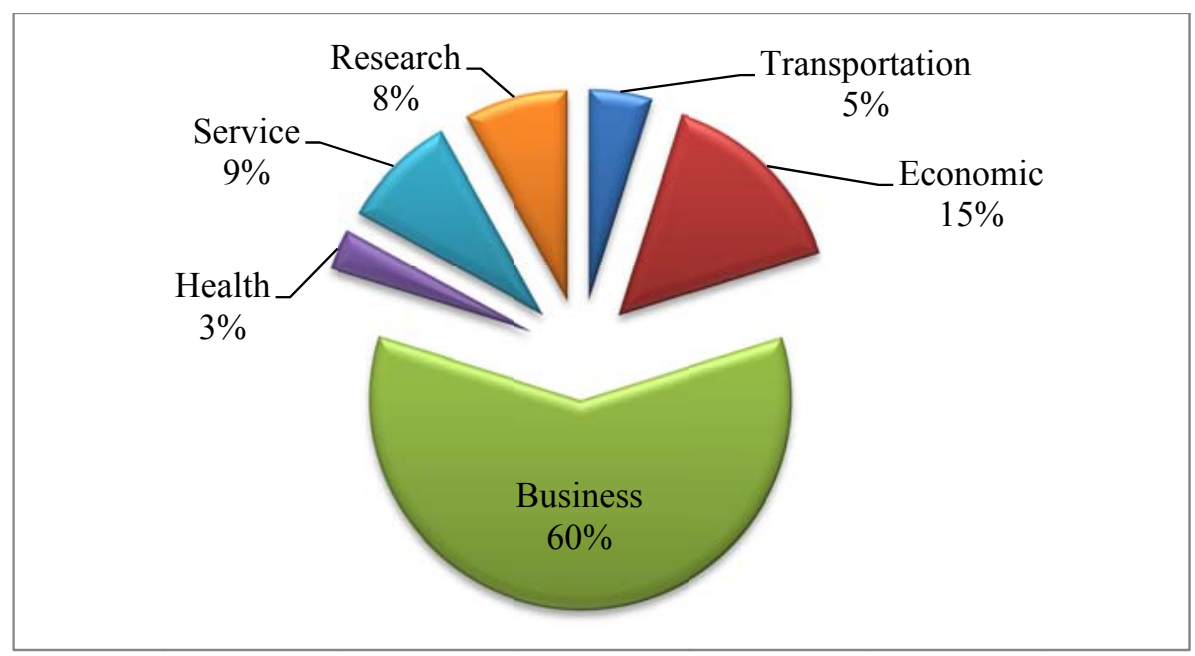

Fig.2.General categories of the application of DEA in industries

\subsection{Network DEA model}

One of the issues in traditional DEA model is the inattention of intermediate products or linking activities and some people have recommended a hybrid of DEA with network problems. Network DEA is complete model and measures the efficiency of a network system including systems connected with more than one process. Using of this model, we one evaluates divisional efficiencies along with the overall efficiency of DMUs. Chen at el. (2011) proposed the method for providing a 
critical evaluation of aggregation of corporate social performance (CSP) and new models of DEA Index. They demonstrated that DEA was independent of subjective weight specifications and provided an efficiency index to benchmark the CSP of firms. Wei at el. (2011) proposed a new DEA model based on the optimal system design to optimally design a DMU new network portfolios to maximize returns on each of decision units.

\subsection{Lexicography}

The primary objective of Lexicography is to prioritize different objectives based on their relative importance. Korhonen and Siitari (2007) used lexicographic parametric programming to rank efficient units in the DEA model. They received the efficiency curve, which was traversing through the efficient frontier from unit to other unit and used the parameterization of the right-hand side vector of the cover problem. Lozano and Villa (2009) implemented AHP and lexicographic to specify a priori a set of preference levels.

\subsection{Analytical Hierarchy Process (AHP)}

Analytical hierarchy process (AHP) is another multi-criteria decision making problem where we ask decision maker to give his/her judgment about the relative priority of one alternative versus another one. There are literally many applications of AHP implementation for supplier selection problem. Sevkli et al. (2007) stated that DEA hierarchy process (DEAHP) method had better performance compared with AHP method for supplier selection. In other words, DEAHP model was more cumbersome to apply and was more suitable for applications of high-value components where careful purchasing criteria were required. They suggested that AHP model used for relatively lower value components. Kuo et al. (2010) used a hybrid of AHP and DEA for developing performance evaluation to make the supplier selection decision. They used the Fuzzy AHP (FAHP) method to find the indicators' weights through expert questionnaire survey and then, these weights were integrated with fuzzy DEA. Then, they used of $\alpha$-cut set and extension principle of fuzzy set theory to simplify the fuzzy DEA. Finally, fuzzy ranking using maximizing and minimizing set method was used to rank the evaluation samples. Zeydan et al. (2011) proposed new method for selecting supplier selection and evaluation quality. They used FAHP to fine criteria weights and then fuzzy TOPSIS (Technique for Order Preference by Similarity to Ideal Solution) to utilize in finding the ranking of suppliers. So, qualitative variables were transformed into a quantitative variable for using in DEA methodology as an output called quality management system audit. Zhang et al. (2012) used combine the DEAHP model and activity-based costing (ABC) for supplier evaluation. This model, make it easy for making decisions on supplier selection and order quantity could easily be made within an integrated single objective function, which is based on consideration of the budget of the buyer and of the capacity of the supplier. This model was based on consideration of the budget of the buyer and of the capacity of the supplier. Kang et al. (2010) applied DEA to evaluate quantitative factors, and the results were transformed into pairwise comparison values for FAHP analysis. Qualitative factors evaluated through FAHP analysis. Lin et al. (2011) integrated DEA and AHP to evaluate the economic development achieved by local governments in China. They also used a time-scale comparison of the economic performances of local governments in China based on the malmquist productivity index (MPI), which stated that there was a trend of economic growth but the results showed that after discounting the advantages of location and political connections, the east district provinces of China did not have superior economic performance or a better MPI index, as compared with other districts. Çelen and Yalçin (2012) performed an investigation on performance assessment of Turkish electricity distribution utilities based on an application of combined FAHP/TOPSIS/DEA methodology to incorporate quality of service.

\subsection{Simple Additive Weighting (SAW)}

In Simple Additive Weighting (SAW) technique, the DM gives weight to each attribute and then, for each option, all values of the parameters that characterize the weight multiply the results together. 
Alternative has the most points is selected as the best choice. Hosseinian et al. (2009) proposed a new method based on DEA for the weight vector derivation from the pair-wise comparison matrices in the group AHP called DEA-WDGD. The purpose of DEA-WDGD is either maximizing outputs or minimizing inputs. They also compared the DEA-WDGD with the DEA method recently proposed for weights derivation in the group AHP. The results indicated that DEA-WDGD provides better weights. The SAW method was also utilized to sum local weights without needing to normalize them.

\subsection{Technique for Order Preference by Similarity to Ideal Solution (TOPSIS)}

Technique for Order Preference by Similarity to Ideal Solution (TOPSIS) chooses the alternative with the shortest distance from the positive ideal alternative and the greatest distance from the negative ideal alternative. Among those who used the DEA method TOPSIS this research can be referred to Tao et al. (2012) who proposed decision model in three parts. First, DEA was used to supply for the best composition on the performance parameters of original data; Second application of Axiomatic Fuzzy Set (AFS) theory and AHP method, the weight of each attribute was calculated and, third, TOPSIS model was applied to provide the ranking order from the best combinations based on the weights of attributes. This model made decision results more reasonable from DMs. Arabzad et al. (2013) proposed the model for choosing supplier based on Kraljic and DEA model. In this method, the purchase items classified to leverage, strategic and routine items. The purpose of this classification was coordination among the purchase items to allocate orders and adopt appropriate and suitable policies with the suppliers of related items. On the other hand, suppliers based upon their performance are categorized by TOPSIS technique. Finally, obtained ranking will be the criteria for the allocation of the purchase orders. Hemmati et al. (2013) used these two MCDM techniques (DEA and TOPSIS) to measure the relative efficiencies banks in terms of electronic payment. Three inputs with DEA methods were considered including the number of issued cards, the number of ATM machines and the number of POSs and two outputs including the number of successful ATMs and the number of successful POSs transactions.

\subsection{Elimination and choice translation reality (ELECTRE)}

Elimination and choice translation reality (ELECTRE) is another MCDM technique for ranking different alternatives (Bernard, 1968). According to Birgün and Cihan (2010) supplier selection is one of the most important issues of the purchasing departments and it is often considered as an MCDM problem. They used ELECTRE for supplier selection problem and discussed how to rank different suppliers based on this method.

\subsection{Green supply chain}

Decision support system (DSS) has also been used for analyzing data and making appropriate decisions for supplier selection problem. Akçay et al. (2012), for instance, developed a general DSS model to investigate the results of implementation of DEA models. They examined the proposed model for a real world project for benchmarking the vendors of a leading Turkish automotive company.

These days, green supply chain management has become a popular research area. Amindoust et al. (2013) applied DEA for supplier selection by considering environmental issues using linguistic terms based on decision makers' opinion. Kuo et al. (2010) developed a green supplier selection framework, which integrated artificial neural network (ANN) and a combination of DEA and analytic network process (ANP). The hybrid ANN-MADA method considered both practicality in traditional supplier selection criteria and environmental regulations. They reported that ANN-MADA had better power of discrimination and noise-insensitivity in evaluating green suppliers' performances. Wen and Chi (2010) developed a criteria set including green, traditional, and partnership issues for the green 
supplier selection problem. They used a combination of DEA, ANP as well as AHP methods to rank different suppliers.

\subsection{Neural Network System}

Neural networks systems (NNS) and computational methods for learning new knowledge obtained acts to more complex systems expected output responses. NNS is performance to display approximation and estimate. Çelebi and Bayraktar (2008) proposed new method of integration of neural networks (NN) and DEA for evaluating of suppliers under incomplete information of evaluation criteria. $\mathrm{Wu}$ (2009) assessed supplier performance by a combine model with DEA, decision trees (DT) and NNs. This model had two steps: first, DEA model was applied and classified suppliers into efficient and inefficient clusters based on the resulting efficiency scores. Second, the model utilized firm performance-related data to train DT, NNs model and apply the trained decision tree model to new suppliers. Shi at el. (2010) proposed a model based on artificial intelligence (BP neural network) and C2R-DEA for selecting appropriate logistics suppliers. In this model they introduced details in the C2R-DEA cross-evaluation method. Samoilenko and Osei-Bryson (2010) proposed a five-step methodology based on DEA, Cluster Analysis (CA) and Neural Networks $(\mathrm{NN})$.

\subsection{Genetic Algorithm (GA)}

Genetic Algorithm (GA) is Darwin's principle of natural selection to find the optimal formula for predicting or use pattern matching. Forecasting techniques based on genetic algorithms for regressions are often a good option. Chuang at el. (2009) used multi-objective genetic algorithm (MOGA) to minimized time and costs of new products developed in conjunction with maximized product reliability. Lin at el. (2013) used a combination of the genetic algorithm (GA) and DEA to evaluate the simulation results and guide the search process and the model was applied to determine optimal resource levels in surgical services.

\section{Conclusion}

In this paper, efforts have been made for the collection of articles associated with the DEA and other problem-solving techniques in various industries. The survey has indicated that DEA method has become the most important technique for ranking supplier selection followed by TOPSIS, AHP. In addition, there were literally various techniques for ranking suppliers using a hybrid of two or more models. We anticipate to have a tremendous breakthrough on using more sophisticated approaches for supplier selection.

\section{References}

Akçay, A.E., Ertek, G., \& Büyüközkan. (2012). analyzing the solutions of DEA through information visualization and data mining techniques: Smart DEA framework. Expert Systems with Applications, 39(9), 7763-7775.

Alem, S.M., Azadeh, A., Shirkouhi, S.N., \& Rezaie, K. (2009). A decision making methodology for vendor selection problem based on DEA, FDEA and CCDEA models. modelling \& simulation. Third Asia International Conference on, 767-770.

Almeida, P.N., \& Dias, L.C. (2012). Value-based DEA models: application-driven developments. Journal of the Operational Research Society, 63, 16-27.

Amado, C.A.F., \& Dyson, R.G. (2009). Exploring the use of DEA for formative evaluation in primary diabetes care: An application to compare english practices. Journal of the Operational Research Society, 60, 1469-1482.

Amindoust, A., Ahmed, Sh., \& Saghafinia, A. (2012). Location decision of supply chain management in the auto motive industry. International Journal of Engineering and Applied Sciences, 1(2), 6467. 
Amindoust, A., Ahmed, Sh., \& Saghafinia, A. (2013). Using data envelopment analysis for green supplier selection in manufacturing under vague environment. Advanced Materials Research, 622, 1682-1685.

Arabzad, S. M., Bahrami,M., \& Ghorbaniz, M. (2012). Integrating Kano-DEA models for distribution evaluation problem. Procedia - Social and Behavioral Sciences, 41, 506-512.

Arabzad, S.M., Kamali, A., Naji, B., \& Ghorbani, M. (2013). DEA and TOPSIS techniques for purchasing management: the case of aircraft manufacturing industry. International Journal of Logistics Systems and Management, 14(2), 242-260.

Azadeh, A., Keramati, A., \& Songhori, M.J. (2009). An integrated Delphi/VAHP/DEA framework for evaluation of information technology/information system (IT/IS) investments. The International Journal of Advanced Manufacturing Technology, 45(11-12), 1233-1251.

Azadeh, A., \& Alem, S.M. (2010). A flexible deterministic, stochastic and fuzzy data envelopment analysis approach for supply chain risk and vendor selection problem: Simulation analysis. Expert Systems with Applications, 37(12), 7438-7448.

Azadi, M., \& Farzipoor Saen, R. (2011). Developing an output-oriented super slacks-based measure model with an application to third-party reverse logistics providers. Journal of Multi-Criteria Decision Analysis, 18(5-6), 267-277.

Azizi, Z., \& Paktinat, M. (2013). A DEA application for analyzing investment activities in higher educational organizations. Management Science Letters, 3(2), 435-442.

Bandyopadhyay, B. (2011). In search of contextual variables in a stochastic DEA framework: Effect of regulation on efficiency of Indian cement industry. Journal of the Operational Research Society, 62, 1621-1637.

Bao, C.P., Chen, T.H., \& Chang, S.Y. (2008). Slack-based ranking method: an interpretation to the cross-efficiency method in DEA. Journal of the Operational Research Society, 59, 860-862.

Barnum, D.T., Gleason, J.M., Hemily, B., Lin, J., \& Wang. P. (2010). Progressing from uncertainty to risk for DEA-based decisions. Journal of the Operational Research Society, 61, 1548-1555.

Bartilow, H.A., \& Eom. K. (2009). Busting drugs while paying with crime: The collateral damage of U.S. drug enforcement in foreign countries. Foreign Policy Analysis, 5(2), 93-116.

Basso, A., \& S Funari, S. (2003). Measuring the performance of ethical mutual funds: a DEA approach. Journal of the Operational Research Society, 54, 521-531.

Bernard, R. (1968). Classement et choix en présence de points de vue multiples (la méthode ELECTRE). La Revue d'Informatique et de Recherche Opérationelle (RIRO), (8), 57-75.

Birgün, S., \& Cihan, E. (2010, November). Supplier selection process using ELECTRE method. In Intelligent Systems and Knowledge Engineering (ISKE), 2010 International Conference on (pp. 634-639). IEEE.

Bowlin, W.F., Renner, C-J., \& Rives, J.M. (2003). A DEA study of gender equity in executive compensation. Journal of the Operational Research Society, 54, 751-757.

Braglia, M., \& Petroni,A. (2000) .A quality assurance-oriented methodology for handling trade-offs in supplier selection. International Journal of Physical Distribution \& Logistics Management, 30(2), 96-112.

Buffa, F.P., \& Ross A.D. (2011). Measuring the consequences of using diverse supplier evaluation teams: A performance frontier perspective. Journal of Business Logistics, 32(1), 55-68.

Chen, C., \& Delmas, M. (2011) Measuring corporate social performance: An efficiency perspective. Production and Operations Management, 20(6), 789-804.

Chen, C., \& Yan, H. (2011). Network DEA model for supply chain performance evaluation. European Journal of Operational Research, 213(1), 147-155.

Chen, Y.J. (2011). Structured methodology for supplier selection and evaluation in a supply chain. Information Sciences, 181(9), 1651-1670.

Chuang, C.L., Chiang, T.A., Che, Z. H., \& Wang, H.S. (2009). Using DEA and GA Algorithm for Finding an Optimal Design Chain Partner Combination. Global Perspective for Competitive Enterprise, Economy and Ecology, 3, 117-127. 
Cook, W.D,. \& Zhu, J. (2011). Output-specific input-assurance regions in DEA. Journal of the Operational Research Society, 62, 1881-1887.

Cordero-Ferrera, J.M., Pedraja-Chaparro, F., \& Santín-González, D. (2010). Enhancing the inclusion of non-discretionary inputs in DEA. Journal of the Operational Research Society, 61, 574-584.

Çelebi, D., \& Bayraktar, D. (2008). An integrated neural network and data envelopment analysis for supplier evaluation under incomplete information. Expert Systems with Applications, 35(4), 16981710.

Çelen, A., \& Yalçin, N. (2012). Performance assessment of Turkish electricity distribution utilities: An application of combined FAHP/TOPSIS/DEA methodology to incorporate quality of service. Utilities Policy, In Press, Corrected Proof, Available online 23 June 2012.

Davoodi, A., Zhiani Rezai, H., Fallahnejad, R. (2012). Congestion analysis in DEA inputs under weight restrictions. Journal of the Operational Research Society, 63, 1089-1097.

Dharmapala, P.s. (2007). On the impact of 'non-uniquely inefficient' decision-making units in DEA on improving efficiency in supply chains: a case from published data. International Journal of Value Chain Management, 1(4), 362-371.

Dotoli, M. (2010). A novel formulation of the DEA model for application to supplier selection. Emerging Technologies and Factory Automation (ETFA). IEEE Conference, 1-8.

Førsund, F.R., \& Hjalmarsson, L. (2004). Calculating scale elasticity in DEA models. Journal of the Operational Research Society, 55, 1023-1038.

Falagario, M., Sciancalepore, F., Costantino, N., \& Pietroforte, R. (2012). Using a DEA-cross efficiency approach in public procurement tenders. European Journal of Operational Research, 218(2), 523-529.

Farzipoor Saen , R. (2010). Restricting weights in supplier selection decisions in the presence of dualrole factors. Applied Mathematical Modelling, 34(10), 2820-2830.

Farzipoor Saen, R. (2010). Performance measurement of power plants in the existence of weight restrictions via slacks-based model. Benchmarking: An International Journal, 17(5), 677-691.

Feng, X.D., \& Jiang, J.H. (2009). Study on the ANP and DEAs quantitative evaluation method for the product innovation supplier in supply chain. Conference: Computer Science and Information Engineering - CSIE, 468-472.

Färe, R., Grosskopf, S., \& Margaritis, D. (2011). The diet problem and DEA. Journal of the Operational Research Society, 62, 1420-1422.

Geymueller, P.V. (2009). Static versus dynamic DEA in electricity regulation: the case of US transmission system operators. Central European Journal of Operations Research, 17(4), 397-413.

Greasley, A. (2005). Using DEA and simulation in guiding operating units to improved performance. Journal of the Operational Research Society, 56, 727-731.

Guedes, E.C.C., Milioni, A.Z., Avellar, J.V.G., \& Silva, R.C. (2012). Adjusted spherical frontier model: allocating input via parametric DEA. Journal of the Operational Research Society, 63, 406-417.

Haralambides, H., \& Gujar, G. (2012). On balancing supply chain efficiency and environmental impacts: An eco-DEA model applied to the dry port sector of India. Maritime Economics \& Logistics, 14, 122-137.

Hatefi, S.M., Jolai, F., Iranmanesh, H., \& Kor, H. (2009). A new DEA model for classification intermediate measures and evaluating supply chain and its nembers. International Conference on Computer Engineering and Technology - ICCE, 1, 457-461.

Hemmati, M., Dalghandi, S.A., \& Nazari, H. (2013). Measuring relative performance of banking industry using a DEA and TOPSIS. Management Science Letters, 3(2), 499-504.

Ho, C.TB., Liao, C.K., \& Kim, H.T. (2011). Valuing internet companies: a DEA-based multiple valuation approach. Journal of the Operational Research Society, 62, 2097-2106.

Hosseinian, S.S., Navidi, H., \& Hajfathaliha, A. (2009). A new method based on data Envelopment analysis to derive weight vector in the group analytic hierarchy process. Journal of Applied Sciences, 9(18), 3343-3349. 
Hu, H.H., Qi, Q., \& Yang, C.H. (2012). Evaluation of China's regional hospital efficiency: DEA approach with undesirable output. Journal of the Operational Research Society, 63, 715-725.

Huang, C.W., Chiu, Y.H., Ting, C.T., \& Lin, C.H. (2012). Applying a hybrid DEA model to evaluate the influence of marketing activities to operational efficiency on Taiwan's international tourist hotels. Journal of the Operational Research Society, 63, 549-560.

Huang, C.Y., Wang, P.Y., \& Tzeng. G.H. (2012). Evaluating top services-prepackaged software firms in standard and poor's 500 index by using a multiple objective programming based data envelopment analysis. Intellgent Decision Technologies Smart Innovation, Systems and Technologies, 16(1), 3-12.

Huang, Y.T., \& Kao, J.J. (2012). Inefficiency countervailed DEA (IC-DEA) method for assessing corporate environmental performance. Journal of the Operational Research Society, 63, 470-477.

Joro, T., \& Viitala, E-J. (2004). Weight-restricted DEA in action: from expert opinions to mathematical models. Journal of the Operational Research Society, 55, 814-821.

Ju, C.H., Jiang, C.B., \& Chen, M.Y. (2012). Research on logistics network infrastructures based on DEA-PCA approach: Evidence from the yangtze river delta region in China. Journal of Shanghai Jiaotong Univertity (Science), 17(1), 98-107.

Kang, H.Y., Lee, A.H.I., \& Chun-Yu L. (2010). A multiple-criteria supplier evaluation model. Computer Communication Control and Automation (3CA), 2, 107-109.

Kang, H.Y., \& Lee, A.H.I. (2010). A new supplier performance evaluation model: A case study of integrated circuit (IC) packaging companies. Kybernetes, 39(1), 489-501.

Kao, L.J., Lu, C.C., \& Chiu, C.C. (2011). The training institution efficiency of the semiconductor institute programme in Taiwan-application of spatiotemporal ICA with DEA approach. Journal of the Operational Research Society, 62, 2162-2172.

Kerstens, K., \& Woestyne, I.V. (2011). Negative data in DEA: a simple proportional distance function approach. Journal of the Operational Research Society, 62, 1413-1419.

Khalili, M., Camanho, A.S., Portela, M.C.A.S., \& Alirezaee, M.R. (2010). An improvement on the Tracy and Chen model 'A generalized model for weight restrictions in DEA'. Journal of the Operational Research Society, 61, 1789-1793.

Krivonozhko, V.E., Utkin, O.B., Volodin, A.V., Sablin, I.A., \& Patrin, M. (2004). Constructions of economic functions and calculations of marginal rates in DEA using parametric optimization methods. Journal of the Operational Research Society, 55, 1049-1058.

Kuo, R.J., Wang, Y.C., \& Tien, F.C. (2010). Integration of artificial neural network and MADA methods for green supplier selection. Journal of Cleaner Production, 18(12), 1161-1170.

Kuo, R.J., Lee, L.Y \& Hu, T.L. (2010). Developing a supplier selection system through integrating fuzzy AHP and fuzzy DEA: a case study on an auto lighting system company in Taiwan. Production Planning \& Control: The Management of Operations, 21(5), 468-484.

Korhonen, P.J., \& Siitari, (2007). Using lexicographic parametric programming for identifying efficient units in DEA. Computers \& Operations Research, 34(7), 2177-2190.

Lin, M.I., Lee, Y.D., \& Ho, T.N. (2011). Applying integrated DEA/AHP to evaluate the economic performance of local governments in China. European Journal of Operational Research, 209(2), 129-140.

Lin, R.C., Sir, M.Y., \& Pasupathy, K.S. (2013). Multi-objective simulation optimization using data envelopment analysis and genetic algorithm: Specific application to determining optimal resource levels in surgical services. The International Journal Management Science-Omega, 41(5), 881892.

Lin, R.H., Chuang, C.L., Liou, J.H., \& Wu, G.D. (2009). An integrated method for finding key suppliers in SCM. Expert Systems with Applications, 36(3), 6461-6465.

Liu, J.S., \& Lu, W.M. (2012). Network-based method for ranking of efficient units in two-stage DEA models. Journal of the Operational Research Society, 63, 1153-1164.

Liu, J., \& Wu, W. (2005). An integrated method for supplier selection in SCM. Services systems and services management, 1. 617-620. 
Liu, J., Ding, F.Y., \& Lall, V. (2000). Using data envelopment analysis to compare suppliers for supplier selection and performance improvement. Supply Chain Management: An International Journal, 5(3), 143-150.

Lozano, S., \& Villa, G. (2009). Multiobjective target setting in data envelopment analysis using AHP. Computers \& Operations Research, 36(2), 549-564.

Lozano, S., \& Villa, G. (2010). DEA-based pre-merger planning tool. Journal of the Operational Research Society, 61, 1485-1497.

Luo, Y., Bi, G., \& Liang, L. (2012). Input/output indicator selection for DEA efficiency evaluation: An empirical study of Chinese commercial banks. Expert Systems with Applications, 39(1), 11181123

Meng, W., Zhang, D., Qi, L., \& Liu, W. (2008). Two-level DEA approaches in research evaluation. The International Journal Management Science-Omega, 36(6), 950-957.

Milioni, A.Z., Avellar, J.V.G., Rabello, T,N., \& Freitas, G,M. (2011). Hyperbolic frontier model: a parametric DEA approach for the distribution of a total fixed output. Journal of the Operational Research Society, 62, 1029-1037.

Mostafa, M.M. (2010). Does efficiency matter?: Examining the efficiency-profitability link in the US specialty retailers and food consumer stores. International Journal of Productivity and Performance Management, 59(3), 255-273.

Noorizadeh, A., Mahdiloo, M., \& Farzipoor Saen, F. (2013). Using DEA cross-efficiency evaluation for suppliers ranking in the presence of non-discretionary inputs. International Journal of Shipping and Transport Logistics, 5(1), 95-111.

Ozbek, M., de la Garza, J., \& Triantis, K. (2009). Data envelopment analysis as a decision-making tool for transportation professionals. Journal of Transportation Engineering, 135(11), 822-831.

Park, K.S. (2007). Efficiency bounds and efficiency classifications in DEA with imprecise data. Journal of the Operational Research Society, 58, 533-540.

Portela. M.C.A.S., \& Thanassoulis, E. (2007). Developing a decomposable measure of profit efficiency using DEA. Journal of the Operational Research Society, 58, 481-490.

Puri, J., \& Yadav, S.P. (2013). A concept of fuzzy input mix-efficiency in fuzzy DEA and its application in banking sector. Expert Systems with Applications, 40(5), 1437-1450.

Rabbani, M. (2009). A new comprehensive framework for ranking accepted orders and supplier selection in make-to-order environments. Computers \& Industrial Engineering.CIE. 919-924.

Ramanathan, R. (2007). Supplier selection problem: integrating DEA with the approaches of total cost of ownership and AHP. Supply Chain Management: An International Journal, 12(4), 494509.

Ramanathan, R. (2005). Estimating energy consumption of transport modes in India using DEA and application to energy and environmental policy. Journal of the Operational Research Society, 56, 732-737.

Revilla, E., Sarkis, J., \& Modrego, A. (2003). Evaluating performance of public-private research collaborations: A DEA analysis. Journal of the Operational Research Society, 54, 165-174.

Ross, A.D., Buffa, F.P., Droge, C., \& Carrington, D. (2009). Using buyer-supplier performance frontiers to manage relationship performance. Journal of the Decision Sciences, 40(1), 37-64.

Ross, A., \& Buffa, F.P. (2009). Supplier post performance evaluation: the effects of buyer preference weight variance. International Journal of Production Research, 47(16), 4351-4371.

Ruiz, J.L,. \& Sirvent, I. (2011). A DEA approach to derive individual lower and upper bounds for the technical and allocative components of the overall profit efficiency. Journal of the Operational Research Society, 62, 1907-1916.

Lozano, S., \& Villa, G. (2005). Centralized DEA models with the possibility of downsizing. Journal of the Operational Research Society, 56, 357-364.

Samoilenko, S., \& Osei- Bryson, K.M. (2012). Using data envelopment analysis (DEA) for monitoring efficiency-based performance of productivity-driven organizations: Design and implementation of a decision support system. The international journal management scienceOmega, Available online 6 February 2012. 
Samoilenko, S., \& Osei-Bryson, K.M. (2010). Determining sources of relative inefficiency in heterogeneous samples: Methodology using cluster analysis, DEA and neural networks. European Journal of Operational Research, 206(2), 479-487.

Saranga, H., \& Moser, R. (2010). Performance evaluation of purchasing and supply management using value chain DEA approach. European Journal of Operational Research, 207(1), 197-205.

Sevkli, M., Lenny Koh, S.C., Zaim, S., Demirbag, M., \& Tatoglu, E. (2007). An application of data envelopment analytic hierarchy process for supplier selection: a case study of BEKO in Turkey. International Journal of Production Research, 45(9), 1973-2003.

Seydel, J. (2006). Data envelopment analysis for decision support. Industrial Management \& Data Systems, 106(1), 81-95.

Shi, C.D., Bian, D.X., \& Li, S.L. (2010). Application of BP neural network and DEA in the logistics supplier selection. Computer Engineering and Technology (ICCET). 2nd International Conference on, 1, 361-364.

Portela, S., Thanassoulis, E., \& Simpson, G. (2004). Negative data in DEA: a directional distance approach applied to bank branches. Journal of the Operational Research Society, 55, 1111-1121.

Sohn, S.Y., \& Kim, Y. (2012). DEA based multi-period evaluation system for research in academia. Expert Systems with Applications, 39(9), 8274-8278.

Soleimani-damaneh, M. (2009). A fast algorithm for determining some characteristics in DEA. Journal of the Operational Research Society, 60, 1528-1534.

Souza, G., Souza, M., \& Gomes, E. (2011). Computing confidence intervals for output-oriented DEA models: an application to agricultural research in Brazil. Journal of the Operational Research Society, 62, 1844-1850.

Talluria, S., Narasimhana, R., \& Nairb, A. (2006). Vendor performance with supply risk: A chanceconstrained DEA approach. International Journal of Production Economics, 100(2), 212-222.

Tao, L., Chen, Y., Liu, X., \& Wang, X. (2012). An integrated multiple criteria decision making model applying axiomatic fuzzy set theory. Applied Mathematical Modelling, 36(10), 5046-5058.

Thanassoulis, E., Kortelainen, M., Johnes, G., \& Johnes, J. (2011). Costs and efficiency of higher education institutions in England: a DEA analysis. Journal of the Operational Research Society, 62, 1282-1297.

Toloo, M., \& Nalchigar, S. (2011). A new DEA method for supplier selection in presence of both cardinal and ordinal data. Expert Systems with Applications, 38(12), 14726-14731.

Tone, K., \& Tsutsui, M. (2009). Network DEA: A slacks-based measure approach. European Journal of Operational Research, 197(1), 243-252.

Triantis, K.P. (2004). Engineering Applications of Data Envelopment Analysis. Hand book on data envelopment analysis, 71, 401-441.

Vakkuri, J. (2003). Research Techniques and Their Use in Managing Non-profit Organizations - An Illustration of DEA Analysis in NPO Environments. Financial Accountability \& Management, 19(3), 243-263.

Vaz, C.B., Camanho, A.S., \& Guimarães, R.C. (2010). The assessment of retailing efficiency using Network Data Envelopment Analysis. Annals of operations research, 173(1), 5-24.

Wang, T.F., \& Cullinane, K. (2006). The Efficiency of European Container Terminals and Implications for Supply Chain Management. Maritime Economics \& Logistics, 8, 82-99.

Wang, Y.M., Chin, K.S., \& Wang, S. (2012). DEA models for minimizing weight disparity in crossefficiency evaluation. Journal of the Operational Research Society, 63, 1079-1088.

Wei, Q.L., \& Chang, T.S. (2011). Optimal system design series-network DEA models. Journal of the Operational Research Society, 62, 1109-1119.

Wei, T., \& Jiansheng, Z. (2010). The Studies of Selecting Service Supplier of Logistics Based on AHP and DEA. E-Product E-Service and E-Entertainment (ICEEE), 1-3.

Wen, U.P., \& Chi, J.M. (2010). Developing green supplier selection procedure: A DEA approach. Industrial Engineering and Engineering Management (IE\&EM), 70-74. 
Wong, W.p., \& Wong, K.Y. (2007). Supply chain performance measurement system using DEA modeling. Industrial Management \& Data Systems. 107(3). 361-381.

Woodbury, K., \& Dollery, B. (2004). Efficiency Measurement in Australian Local Government: The Case of New South Wales Municipal Water Services. Review of Policy Research, 21(5), 615-636.

Wu, D. (2009). Supplier selection: A hybrid model using DEA, decision tree and neural network. Expert Systems with Applications, 36(5), 9105-9112.

Wu, D.D. (2010). A systematic stochastic efficiency analysis model and application to international supplier performance evaluation. Expert Systems with Applications, 37(9), 6257-6264.

$\mathrm{Wu}$, J., Yan, H., Liu, J. (2010). DEA models for identifying sensitive performance measures in container port evaluation. Maritime Economics \& Logistics, 12, 215-236.

Wu, T., \& Blackhurst, J. (2009). Supplier evaluation and selection: an augmented DEA approach. International Journal of Production Research, 47(16), 4593-4608.

Wu, D., \& Olson, D L. (2012). A comparison of stochastic dominance and stochastic DEA for vendor evaluation. International Journal of Production Research, 46(8), 2313-2327.

$\mathrm{Xu}$, C., Liang, S., Jiang, J., Liu, D., \& Huang, Sh. (2010). A study on supplier evaluation in risk control based on food supply chain. Management of Innovation and Technology (ICMIT), 181185.

$\mathrm{Xu}, \mathrm{J} ., \mathrm{Li}, \mathrm{B} ., \mathrm{W}_{\mathrm{Wu}}$ D. (2009). Rough data envelopment analysis and its application to supply chain performance evaluation. International Journal of Production Economics, 122(2), 628-638.

Xuanli L., \& Yuan, D.Y. (2011). Modeling the region manufacturing innovation ability with ICA and DEA. Mechanic Automation and Control Engineering (MACE), 433-436.

You, S., \& Yan, H. (2011). A new approach in modelling undesirable output in DEA model. Journal of the Operational Research Society, 62, 2146-2156.

Zeydan, M., Çolpan, C., \& Çobanoglu., C. (2011). A combined methodology for supplier selection and performance evaluation. Expert Systems with Applications, 38(3), 2741-2751.

Zhang, X., Lee, C.K.M., \& Chen, S. (2012). Supplier evaluation and selection: a hybrid model based on DEAHP and ABC. International Journal of Production Research, 50(7), 1877-1889.

Zhao, X., \& Sun, L. (2008). A Preference Restraint DEA Approach for Supplier Selection. International Conference on Wireless Communications, Networking and Mobile Computing WiCom.1-4.

Zhenhua, G. (2009). The Application of DEA/AHP Method to Supplier Selection. Conference: International Conference on Information Management, Innovation Management and Industrial Engineering - ICIII, 2, 449-451.

Zhou, P., Leng-Poh, K., \& Wah-Ang, B. (2011). A non-radial DEA approach to measuring environmental performance. European Journal of Operational Research, 178(1), 1-9. 